\title{
PENGEMBANGAN MEDIA PEMBELAJARAN INTERAKTIF BERBASIS KOMPUTER PADA MENGGAMBAR TEKNIK
}

\author{
Nur Basuki dan Harun Sitompul \\ FT Universitas Negeri Medan dan PPs Universitas Negeri Medan \\ norbasuki@gmail.com
}

\begin{abstract}
Abstrak: Penelitian ini bertujuan untuk: menghasilkan media pembelajaran interaktif yang layak digunakan, mudah dipelajari mahasiswa dan dapat dipakai untuk pembelajaran individual, mengetahui keefektifan media pembelajaran interaktif yang dikembangkan pada matakuliah menggambar teknik. Jenis penelitian ini adalah penelitian pengembangan yang menggunakan model Borg \& Gall yang dipadu dengan model Dick \& Carey. Hasil pengebangan menunjukkan bahwa uji ahli dan uji coba yang dilakukan kualifikasi sangat baik dengan melalui tahapan revisi produk. Metode yang digunakan dalam penelitian adalah kuasi eksperimen. Hasil pengujian hipotesis membuktikan bahwa terdapat perbedaan yang signifikan antara hasil belajar mahasiswa yang dibelajarkan dengan menggunakan media pembelajaran interaktif dengan media pembelajaran buku teks. Hal ini ditunjukkan dengan hasil pengolahan data dan disimpulkan bahwa hasil belajar kelompok mahasiswa yang dibelajarkan dengan menggunakan media pembelajaran interaktif lebih tinggi dari yang dibelajarkan dengan menggunakan media pembelajaran buku teks.
\end{abstract}

Kata Kunci: pengembangan media pembelajaran interaktif berbasis komputer, menggambar teknik

\begin{abstract}
This study aims to: produce a viable interactive learning media use, easy to learn students and can be used for individual learning, knowing the effectiveness of interactive learning media were developed in the course drawing techniques. This type of research is the development of research that uses models Borg \& Gall combined with Dick \& Carey model. Pengebangan results show that the expert test and qualification testing performed very well with through the stages of a product revision. The method used in the study was a quasi-experimental. Hypothesis testing results prove that there is a significant difference between the learning outcomes of students who learned with using the medium of interactive learning with instructional media textbook. This is shown by the results of data processing and concluded that the results of the study group of students that learned by using interactive learning media is higher than that learned by using learning media textbook.
\end{abstract}

Keywords: development of a computer -based interactive learning media, drawing techniques

\section{PENDAHULUAN}

Dalam pembelajaran menggambar teknik banyak mahasiswa beranggapan bahwa mata kuliah menggambar teknik merupakan mata kuliah yang sulit dan tidak menarik. Hal ini kemungkinan disebabkan kesulitan dalam membaca gambar sesuai dengan standar ISO. Dalam pembuatan gambar kerja harus menunjukkan karakteristik-karakteristik yang khas dan komplit, dengan terdapat dimensi, symbol, irisan yang sesuai dengan standar ISO. Urutan gambar kerja terkait dengan menggambar teknik yang merupakan sarana komunikasi penting bagi orang teknik, meliputi perancang, pekerja, dalam suatu industri. Tetapi menggambar teknik juga dapat memberikan kemudahan dalam membuat produk yang diinginkan untuk tugas menggambar teknik pada matakuliah menggambar teknik maupun oleh industry. Pengajaran menggambar mesin yang selama ini dilakukan tidak terorganisir dengan baik, sehingga perolehan belajar mahasiswa rendah yaitu sebesar $63,45 \%$ menguasai, selebihnya mahasiswa belum mampu memahami dan mengaplikasikan gambar kerja dalam menggambar teknik dengan baik dan benar (Mursid, 2010:2). Hal ini menunjukkan adanya kesenjangan antara harapan dan kenyataan yang ada. Untuk itu perlu adanya peningkatan prestasi belajar menggambar teknik dengan mempertimbangkan berbagai faktor yang mempengaruhi proses pembelajaran dan keberhasilan belajar menggambar teknik.

Dalam era globalisasi saat ini, peningkatan proses dan hasil pembelajaran 
menggambar teknik harus dapat dilakukan secara efisien dan efektif. Bila hal ini tidak dilakukan, ketinggalan kita dengan negara lain akan semakin jauh. Kecenderungan baru (trend) teknologi pembelajaran menggambar teknik seharusnya dicermati dan secara skala prioritas kita laksanakan, sesuai dengan tekad dan kemampuan kita bersama. Perubahan tersebut menurut Sukardjo (2000) mengikuti kecenderungan (trend) tertentu, di antaranya: kurikulum yang semula berorientasi pada materi menggambar teknik (subject matter oriented) cenderung berubah menjadi kurikulum yang berorientasi pada hasil (output oriented) dan proses (process oriented) mencapai hasil. Pembelajaran yang semula berpusat pada guru atau dosen (teacher centered) cenderung berubah menjadi berpusat pada mahasiswa (student centered). Pengorganisasian kelas yang semula bersifat konvensional berubah menjadi kelompok, bahkan individual. Buku ajar yang semula berisi seluruh konsep cenderung berubah menjadi buku ajar yang berisi satu konsep dalam bentuk paket-paket belajar. Media pembelajaran yang semula berupa media konvensional cenderung berubah menjadi media elektronik.

Mahasiswa yang sudah terbiasa mengikuti pelajaran secara konvensional akan mengalami kesulitan apabila mereka diarahkan untuk belajar secara mandiri. Karena belajar secara individual membuktikan disiplin belajar yang tinggi, mempunyai kemauan yang kuat untuk belajar mencapai sukses memiliki motivasi untuk berprestasi dan adanya persaingan antar mahasiswa untuk mencapai tingkat prestasi yang optimal. Pembelajaran individual bertujuan agar para mahasiswa belajar secara optimal dan harus dapat mencapai tingkat penguasaan bahan pelajaran yang dipelajarinya. Kelebihan yang dimiliki dalam pembelajaran individual adalah adanya perlakuan khusus kepada mahasiswa secara individual, yang berbeda minat, kemampuan, kebutuhan, serta kecepatan belajarnya. Kesadaran dalam diri mahasiswa akan tanggung jawab terletak pada kemauan, minat, ketekunan dan cita-cita yang tinggi.

Melihat kenyataan tersebut, perlu adanya pengembangan media pembelajaran interaktif berbasis komputer pada matakuliah menggambar teknik di Fakultas Teknik Jurusan Pendidikan Teknik. Dengan pengembangan media interaktif ini diharapkan dapat membantu dosen dalam menjelaskan berbagai bahasan materi kuliah, sehingga dosen tidak lagi hanya bergantung pada buku pelajaran maupun diktat yang ada. Para mahasiswa sebagai penerima materi perkuliahan, akan lebih mudah dalam memahami materi yang disampaikan. Penelitian ini merupakan upaya untuk mengembangkan media pembelajaran interaktif untuk matakuliah menggambar teknik di jurusan Pendidikan Teknik Mesin Universitas Negeri Medan dengan berbagai macam software dan Macromedia Flash Professional 8.0.

Kemampuan membaca gambar teknik mesin dapat dilihat dari hasil bacaannya, jadi bukan prosedurnya, hal ini disebabkan karena kegiatan itu menyangkut proses mental seperti misalnya keterampilan memecahkan masalah (Gronlund 1982:83-84). Gambar teknik mesin harus dapat memberikan informasi untuk meneruskan maksud apa yang diinginkan oleh perencana kepada pelaksana (tekniks). Demikian juga apa yang diinginkan oleh perencana kepada pelaksana (teknisi). Demikian juga pelaksana harus mampu membaca apa yang terdapat dalam gambar kerja untuk dibuat menjadi produk yang sebbenarnya sesuai dengan keinginan perencana atau pemesan. Untuk itu standar-standar, sebagai tata bahasa teknik, diperlukan untuk menyediakan ketentuan-ketentuan yang cukup (Sato dan Sigiarto 1994:2).

Gambar teknik yang dibuat harus dapat memberikan pada bidang yang sesuai dan aturan-aturan yang benar (Gisecke dkk. 1985:8). Untuk dapat menggunakan gambar sebagai bahasa, orang perlu mempunyai kemampuan: memahami gambar teknik, membuat sketsa-sketsa yang digambar secara bebas atau diagram-diagram detail, penguasaan seluruh lingkup teknik menggambar yang khas bagi gambar kerjadalam lapangan kejuruan yang relevan, dan membuat gambar rancangan lengkap (Nolker dan Schoenfeldt 1988: 149150). Dari apa yang telah diuraikan tersebut dapat dimengerti bahwa untuk dapat membaca gambar teknik mesin diperlukan kontruk (construct) kemampuan membaca: aturan gambar, pandangan gambar, serta bentangan, detail dan gambar susunan.

Gambar teknik modern cenderung menstandarisasikan tanda-tanda (character) bahasa gambar untuk menghilangkan kedaerahan dan bahasa daerah dan memberikan kepada lingkungan industry, penerapan teknik dan ilmu pengetahuan suatu bahasa gambar yang seragam dan efektif. Usaha yang sangat membantu ini, di Amerika serikat merupakan 
hasil kerja dari Amerika National Standards Institute (ANSI). Bersama American Societi for engineering education, Socity of Automotive Engineering dan American Societi of mechanical Engineerings.

Model pengembangan pembelajaran berfungsi mengarahkan kita untuk mendesaian pembelajaran yang digunakan sebagai pedoman dalam penyelenggaraan pembelajaran agar teracapai pembelajaran yang efektif, efisien, berdaya guna menarik dan humanis. Fungsi lain sebagai alat berkomunikasi dan petunjuk dalam perencanaan aktivitas yang akan dilaksanakan pada pengelolaan atau pengambilan keputusan. Model Dick \& Carey (2005 : 9) adalah salah satu contoh model pengembangan yang berorientasi pada hasil, karena penerapan konsep-konsep dan prinsip-prinsip perancangannya akan menghasilkan bahan belajar mandiri.

Dasar pemikiran pembelajaran individual adalah adanya pengakuan terhadap perbedaan individu masing-masing mahasiswa. Apabila pembelajaran konvensional menekankan pada persamaannya, maka pembelajaran individual menekankan perbedaan. Menurut Haryanto (1996) pembelajaran individual bertujuan: (1) Membantu mahasiswa yang mengalami kesulitan belajar, (2) Melayani perbedaan individu mahasiswa dalam belajar dan memperhatikan kepentingannya serta individual, (3) Meningkatkan mutu dan efektivitas proses pembelajaran, (4) Pelaksanaan pembelajaran yang disesuaikan dengan kemampuan dan minat individu mahasiswa, (5) Memberi kesempatan seluasluasnya pada mahasiswa untuk mengembangkan potensinya secara optimal.

Salah satu sistem pembelajaran yang sesuai dengan pembelajaran individual adalah pembelajaran dengan modul seperti yang dikemukakan oleh Kemp (1994: 147). Istilah modul pada awalnya merupakan istilah dalam bidang teknik yang diambil oleh dunia pendidikan untuk menunjukkan suatu konsep baru tentang unit program pembelajaran. Menurut Russel (1973: 13), sumber belajar yang berupa pembelajaran mandiri mempunyai ciri-ciri umum, yaitu: (1) Self- contained, self instroduction packase, (2) Concern for individual differencesof knowledge, (3) Statement of objectives, (3) Assosiation, structure and sequnce of knowledge, (4) Utilization of varieties of media, (5) Active partisipation by the leaner, (6) Immediate evaluation stategy.

Penelitian dan pengembangan ini bertujuan untuk: (1) Menghasilkan media pembelajaran interaktif berbasis komputer pada matakuliah menggambar teknik yang berkualitas, mudah dipelajari dan dipahami mahasiswa serta dapat digunakan untuk pembelajaran individual; dan (2) Untuk melihat hasil implementasi media pembelajaran interaktif berbasis komputer pada matakuliah menggambar teknik.

\section{METODE PENELITIAN}

Penelitian ini dilaksanakan di Fakultas Teknik mahasiswa semester I Jurusan Pendidikan Teknik Mesin Universitas Negeri Medan. Metode penelitian yang digunakan adalah research and development, karena penelitian ini termasuk penelitian pengembangan pendidikan yang dimaksudkan untuk menghasilkan produk pembelajaran yang layak dimanfaatkan dan sesuai kebutuhan. Model pengembangan merupakan serangkaian prosedur dalam rangka menghasilkan media pembelajaran mata kuliah gambar teknik untuk mahasiswa (Mahasiswa Jurusan Pendidikan Teknik Mesin UNIMED) Semester I. Model pengembangan yang dipakai merupakan adaptasi dari model pengembangan multimedia Luther (Ariesto Hadi S., 2003: 32), dan model pengembangan pembelajaran versi Program Pekerti 2001 yang telah disesuaikan dengan Kurikulum 2004 (Mukminan, 2004: 18). Adapun langkah-langkah dari tahapan pengembangannya adalah sebagai berikut :

1. Melakukan penelitian pendahuluan, yang meliputi:

a. Identifikasi kebutuhan pembelajaran dan menentukan standar kompetensi mata pelajaran.

b. Melakukan analisis pembelajaran.

c. Mengidentifikasi karakteritik dan perilaku awal mahasiswa.

d. Menulis kompetensi dasar dan indikatornya.

e. Menulis tes acuan patokan.

f. Menyusun strategi pembelajaran yang diwujudkan dalam bentuk silabus dan satuan pembelajaran.

g. Mengembangkan materi pembelajaran.

2. Pembuatan desain software, yang meliputi:

a. Pembuatan naskah

b. Pembuatan storyboard

c. Pembuatan flowchart view

3. Pengumpulan bahan, yang meliputi: 
a. Pembuatan dan pengumpulan gambar (image) dan animasi.

b. Perekaman dan pengumpulan audio

4. Mengembangkan dan membuat Media Pembelajaran Interaktif Berbasis Komputer Pada Matakuliah Menggambar Teknik.

5. Review dan uji coba produk.

Analisis data dalam penelitian ini menggunakan analisis deskriptif kuantitatif. Semua data yang terkumpul dianalisis dengan teknik statistik deskriptif yang secara kuantitatif dipisahkan menurut kategori untuk mempertajam penilaian dalam menarik kesimpulan. Data kualitatif yang berupa pernyataan sangat kurang baik, kurang baik, sedang, baik dan sangat baik diubah menjadi data kuantitatif dengan skala nilai 1 sampai 5 . Hasilnya dirata-rata dan digunakan untuk menilai kualitas software pembelajaran. Kriteria software akan dikonversikan menjadi nilai dengan skala lima menggunakan Skala Likert yang dianalisis secara deskriptif persentase dengan rumus sebagai berikut (Sugiyono, 2007).

Populasi dalam penelitian ini adalah mahasiswa jurusan pendidikan teknik mesin Universitas Negeri Medan angkatan 2011/2012 yang berjumlah 58 orang yang terbagi dua kelas, yaitu kelas A sebagai kelas eksperimen dan kelas B sebagai kelas kontrol masingmasing sebanyak 29 orang.

Dalam penelitian ini data yang diperoleh adalah hasil belajar siswa dari kelas eksperimen dan kelas kontrol. Teknik analisis data yang digunakan adalah teknik deskriptif dan Inferensial. Teknik deskriptif adalah statistik yang digunakan untuk menganalisis data dengan cara menggambarkan data yang telah terkumpul sebagaimana adanya tanpa bermaksud membuat kesimpulan yang berlaku untuk umum atau generalisasi. Misalnya penyajian data menggunakan table, grafik, diagram lingkaran, pictogram, perhitungan modus, median, mean, desil, persentil, rata-rata, standar defiasi, porsentasi, korelasi, dan regresi tanpa pengujian signifikasi. Dan teknik inferensial adalah teknik statistik untuk menganalisis data sampel data dan hasilnya diberlakukan untuk populasi. Suatu kesimpulan dari data sampel yang akan diberlakukan untuk populasi itu mempunyai peluang kesalahan dan kebenaran (kepercayaan).
Hipotesis penelitian yang akan diuji adalah :

Ho : $\mu_{1}=\mu_{2}$

$\mathrm{Ha}: \mu_{1}>\mu_{2}$

Keterangan :

$\mu_{1}=$ Rata-rata hasil belajar mahasiswa yang diajar menggukan media pembelajaran interaktif.

$\mu_{2}=$ Rata-rata hasil belajar mahasiswa yang diajar dengan pembelajaran konvensional.

Ho = Tidak ada perbedaan hasil belajar menggambar teknik mahasiswa yang diajar dengan menggunakan media pembelajaran interaktif berbasis komputer lebih tinggi dari mahasiswa yang diajar dengan pembelajaran konvensional.

$\mathrm{Ha}=\mathrm{Ada}$ perbedaan hasil belajar menggambar teknik mahasiswa yang diajar dengan menggunakan media pembelajaran interaktif berbasis komputer lebih tinggi dari mahasiswa yang diajar dengan pembelajaran konvensional.

Untuk uji hipotesis digunakan rumus uji dua pihak. Kriteria pengujian terima Ha jika $\mathrm{t}_{\text {hitung }}>\mathrm{t}_{\text {tabel }}$ yang didapat dari daftar distribusi $\mathrm{t}$ dengan $\mathrm{dk}=(\mathrm{n}-1)$ dan taraf $\alpha=5 \%$. Untuk melihat nilai keefektifan media pembelajaran interaktif yang dieksperimenkan digunakan rumus perhitungan efektifitas.

\section{HASIL DAN PEMBAHASAN \\ Hasil \\ Data Hasil Uji Coba Tahap II Uji Coba Perorangan}

Uji coba perorangan dilakukan pada 3 mahasiswa yang terdiri dari 1 mahasiswa yang memiliki prestasi tinggi, 1 orang yang berprestasi sedang dan 1 orang yang berprestasi rendah. Tujuan dari uji coba perorangan ini adalah untuk mengidentifikasi kekurangan produk pembelajaran setelah ditinjau ulang oleh tenaga ahli. Penilaian dan masukan dari uji coba ini adalah tentang penyajian produk pembelajaran meliputi aspek kualitas materi pembelajaran dan aspek kualitas teknis atau tampilan yang terdapat dalam media pembelajaran interaktif berbasis computer pada matakuliah menggambar teknik.

Tabel 1. Skor Penilaian Media Pembelajaran Interaktif Berbasis Komputer Pada Matakuliah Menggambar Teknik Pada Uji Coba Perorangan Tentang Kualitas Materi Pembelajaran 


\begin{tabular}{|c|c|c|c|c|c|c|c|}
\hline \multirow{2}{*}{ No } & \multirow{2}{*}{ Indikator Penilaian } & \multicolumn{3}{|c|}{ Responden } & \multirow{2}{*}{$\begin{array}{l}\text { Jumlah } \\
\text { Skor }\end{array}$} & \multirow{2}{*}{ Rata-rata } & \multirow{2}{*}{ Kriteria } \\
\hline & & 1 & 2 & 3 & & & \\
\hline 1 & Kesesuaian materi & 5 & 4 & 5 & 14 & $93,33 \%$ & Sangat Baik \\
\hline 2 & Kejelasan petunjuk belajar & 5 & 5 & 5 & 15 & $100,00 \%$ & Sangat Baik \\
\hline 3 & $\begin{array}{l}\text { Kemudahan memahami kalimat } \\
\text { pada teks }\end{array}$ & 4 & 5 & 5 & 15 & $93,33 \%$ & Sangat Baik \\
\hline 4 & $\begin{array}{l}\text { Kemudahanmemahami } \\
\text { pembelajaran }\end{array}$ & 4 & 4 & 5 & 13 & $86,67 \%$ & Sangat Baik \\
\hline 5 & Ketepatan urutan penyajian & 5 & 5 & 4 & 14 & $93,33 \%$ & Sangat Baik \\
\hline 6 & Kecukupan latihan & 4 & 4 & 5 & 13 & $86,67 \%$ & Sangat Baik \\
\hline 7 & Kejelasan umpan balik & 5 & 5 & 4 & 14 & $93,33 \%$ & Sangat Baik \\
\hline \multirow[t]{2}{*}{8} & Bantuan belajar dengan program & 5 & 5 & 5 & 13 & $100,00 \%$ & Sangat Baik \\
\hline & \multicolumn{4}{|l|}{ Rata-rata } & 93,33 & $93,33 \%$ & Sangat Baik \\
\hline
\end{tabular}

Tabel 2. menunjukkan tanggapan 3 mahasiswa pada uji coba perorangan terhadap media pembelajaran interaktif dari aspek kualitas materi pembelajaran dan secara keseluruhan dinyatakan dalam kriteria "Sangat Baik".

Tabel 2. Skor Penilaian Media Pembelajaran Interaktif Berbasis Komputer Matakuliah Menggambar Teknik PadaUji Coba Perorangan Tentang Aspek Kualitas Teknis/Tampilan

\begin{tabular}{|l|l|c|c|c|c|c|c|}
\hline \multirow{2}{*}{ No } & \multicolumn{1}{|c|}{ Indikator Penilaian } & \multicolumn{3}{|c|}{ Responden } & Jumlah & \multirow{2}{*}{ Rata-rata } & \multirow{2}{*}{ Kriteria } \\
\cline { 3 - 5 } & & 1 & 2 & 3 & Skor & & \\
\hline 1 & Keindahan Tampilan layar & 5 & 5 & 4 & 14 & $93,33 \%$ & Sangat Baik \\
\hline 2 & Keterbacaan teks & 4 & 4 & 4 & 12 & $80,00 \%$ & Sangat Baik \\
\hline 3 & Kualitas gambar dan animasi & 5 & 5 & 5 & 15 & $100,00 \%$ & Sangat Baik \\
\hline 4 & Komposisi warna & 5 & 5 & 4 & 14 & $93,33 \%$ & Sangat Baik \\
\hline 5 & Navigasi & 5 & 4 & 4 & 13 & $86,67 \%$ & Sangat Baik \\
\hline 6 & Daya dukung musik & 4 & 4 & 4 & 12 & $80,00 \%$ & Sangat Baik \\
\hline 7 & Interaksi & 4 & 5 & 5 & 14 & $93,33 \%$ & Sangat Baik \\
\hline & \multicolumn{2}{|c}{ Rata-rata } & & 89,52 & $89,52 \%$ & Sangat Baik \\
\hline
\end{tabular}

Tanggapan mahasiswa pada uji coba perorangan ditunjukkan pada Tabel 2 dijelaskan bahwa media pembelajaran interaktif dari aspek kualitas teknis atau tampilan mayoritas dinilai secara keseluruhan dinilai "Sangat Baik".

\section{Data Hasil Uji Coba Tahap III Uji Coba Kelompok Kecil}

mahasiswa yang berprestasi tinggi, 3 mahasiswa yang berprestasi sedang, dan 3 mahasiswa yang berprestasi rendah dimaksudkan untuk mengetahui beberapa kelemahan atau hambatan yang dihadapi ketika produk media pembelajaran interaktif digunakan

Uji coba kelompok kecil dilakukan terhadap 9 orang mahasiswa yang terdiri dari 3

Tabel 3. Skor Penilaian Media Pembelajaran Interaktif Berbasis Komputer Pada Matakuliah Menggambar teknik Uji Coba Kelompok Kecil Pada Aspek Kualitas Materi pembelajaran

\begin{tabular}{|c|c|c|c|c|c|c|c|c|}
\hline \multirow{2}{*}{ No } & \multirow{2}{*}{ Indikator Penilaian } & \multicolumn{5}{|c|}{ Skor } & \multirow{2}{*}{ Rata-rata } & \multirow{2}{*}{ Kriteria } \\
\hline & & 1 & 2 & 3 & 4 & 5 & & \\
\hline 1 & Kesesuaian materi & & & & 6 & 3 & $86,67 \%$ & Sangat Baik \\
\hline 2 & Kejelasan petunjuk belajar & & & & 4 & 5 & $91,11 \%$ & Sangat Baik \\
\hline 3 & $\begin{array}{l}\text { Kemudahan memahami kalimat } \\
\text { pada teks }\end{array}$ & & & & 4 & 5 & $91,11 \%$ & Sangat Baik \\
\hline 4 & $\begin{array}{l}\text { Kemudahan memahami } \\
\text { pembelajaran }\end{array}$ & & & & 6 & 3 & $86,67 \%$ & Sangat Baik \\
\hline
\end{tabular}




\begin{tabular}{|l|l|l|l|l|l|l|l|l|}
\hline \multirow{2}{*}{ No } & \multirow{2}{*}{ Indikator Penilaian } & \multicolumn{5}{|c|}{ Skor } & \multirow{2}{*}{ Rata-rata } & \multirow{2}{*}{ Kriteria } \\
\cline { 3 - 9 } & & 1 & 2 & 3 & 4 & 5 & & \\
\hline 5 & Ketepatan urutan penyajian & & & & 2 & 7 & $95,56 \%$ & Sangat Baik \\
\hline 6 & Kecukupan latihan & & & & 3 & 6 & $93,33 \%$ & Sangat Baik \\
\hline 7 & Kejelasan umpan balik & & & & 4 & 5 & $91,11 \%$ & Sangat Baik \\
\hline 8 & Bantuan belajar dengan program & & & & 2 & 7 & $95,56 \%$ & Sangat Baik \\
\hline \multicolumn{7}{|c|}{ Rata-rata } \\
\hline
\end{tabular}

Penilaian pada aspek kualitas materi pembelajaran untuk uji coba kelompok kecil yang tampak pada Tabel 3 menunjukkan bahwa secara keseluruhan dalam kriteria "Sangat Baik".

Tabel 4. Skor Penilaian Media Pembelajaran Interaktif Berbasis Komputer Pada Matakuliah Menggambar teknikUji Coba Kelompok Kecil Pada Aspek Kualitas Teknis atau Tampilan

\begin{tabular}{|l|l|l|l|l|l|l|l|l|}
\hline \multirow{2}{*}{ No } & \multirow{2}{*}{ Indikator Penilaian } & \multicolumn{5}{|c|}{ Skor } & \multirow{2}{*}{ Rata-rata } & \multirow{2}{*}{ Kriteria } \\
\cline { 3 - 8 } & & 1 & 2 & 3 & 4 & 5 & & \\
\hline 1 & Keindahan tampilan layar & & & & 1 & 8 & $97,78 \%$ & Sangat Baik \\
\hline 2 & Keterbacaan teks & & & & & 9 & $100,00 \%$ & Sangat Baik \\
\hline 3 & Kualitas gambar dan animasi & & & & 2 & 7 & $95,56 \%$ & Sangat Baik \\
\hline 4 & Komposisi warna & & & & 3 & 6 & $93,33 \%$ & Sangat Baik \\
\hline 5 & Navigasi & & & & 1 & 7 & $86,67 \%$ & Sangat Baik \\
\hline 6 & Daya dukung musik & & & & 1 & 8 & $97,78 \%$ & Sangat Baik \\
\hline 7 & Interaksi & & & & & 9 & $100,00 \%$ & Sangat Baik \\
\hline \multicolumn{2}{|c|}{ Rata-rata } & & & $95,87 \%$ & Sangat Baik \\
\hline
\end{tabular}

\section{Data Hasil Uji Coba Tahap IV Uji Coba} Lapangan

Uji coba lapangan dilakukan terhadap mahasiswa teridiri dari 58 mahasiswa dari dua kelas yaknik kelas A sebanyak 29 mahasiswa dan kelas B sebanyak 29 mahasiswa. Uji coba lapangan menghasilkan data-data yang nantinya akan mengukur kelayakan dari produk yang dikembangkan, serta untuk mengetahui bagaimana manfaat produk tersebut bagi pemakainya.

Tabel 5. Skor Penilaian Media Pembelajaran Interaktif Berbasis Komputer Menggambar Teknik Uji Coba Lapangan Pada Aspek Kualitas Materi Pembelajaran

\begin{tabular}{|c|c|c|c|c|c|c|c|c|}
\hline \multirow{2}{*}{ No } & \multirow{2}{*}{ Indikator Penilaian } & \multicolumn{5}{|c|}{ Skor } & \multirow{2}{*}{ Rata-rata } & \multirow{2}{*}{ Kriteria } \\
\hline & & 1 & 2 & 3 & 4 & 5 & & \\
\hline 1 & Kesesuaian materi & & & & 6 & 52 & $97,93 \%$ & Sangat Baik \\
\hline 2 & Kejelasan petunjuk belajar & & & & 3 & 55 & $98,97 \%$ & Sangat Baik \\
\hline 3 & $\begin{array}{l}\text { Kemudahan memahami kalimat } \\
\text { pada teks }\end{array}$ & & & & 13 & 45 & $95,52 \%$ & Sangat Baik \\
\hline 4 & $\begin{array}{l}\text { Kemudahan memahami } \\
\text { pembelajaran }\end{array}$ & & & & 10 & 48 & $96,55 \%$ & Sangat Baik \\
\hline 5 & Ketepatan urutan penyajian & & & & 5 & 53 & $98,28 \%$ & Sangat Baik \\
\hline 6 & Kecukupan latihan & & & & 13 & 45 & $95,52 \%$ & Sangat Baik \\
\hline 7 & Kejelasan umpan balik & & & & & 58 & $100,00 \%$ & Sangat Baik \\
\hline 8 & Bantuan belajar dengan program & & & & & 58 & $100,00 \%$ & Sangat Baik \\
\hline \multicolumn{7}{|c|}{ Rata-rata } & $97,84 \%$ & Sangat Baik \\
\hline
\end{tabular}

Hasil evaluasi terhadap media pembelajaran pada aspek kualitas teknis atau tampilan menunjukkan hasil tanggapan mahasiswa pada aspek kualitas teknis atau tampilan untuk uji coba lapangan dan keseluruhannya dalam kriteria "Sangat Baik". 
Tabel 6. Skor Penilaian Media Pembelajaran Interaktif Berbasis Komputer Pada Matakuliah Menggambar teknik Uji Coba Lapangan Pada Aspek Kualitas Teknis atau Tampilan

\begin{tabular}{|c|l|c|c|c|c|l|c|l|}
\hline \multirow{2}{*}{ No } & \multirow{2}{*}{ Indikator Penilaian } & \multicolumn{5}{|c|}{ Skor } & \multirow{2}{*}{ Rata-rata } & \multirow{2}{*}{ Kriteria } \\
\cline { 3 - 8 } & & 1 & 2 & 3 & 4 & 5 & & \\
\hline 1 & Keindahan tampilan layar & & & & & 58 & $100,00 \%$ & Sangat Baik \\
\hline 2 & Keterbacaan teks & & & & & 58 & $100,00 \%$ & Sangat Baik \\
\hline 3 & Kualitas gambar dan animasi & & & & 5 & 53 & $98,28 \%$ & Sangat Baik \\
\hline 4 & Komposisi warna & & & & 15 & 43 & $94,83 \%$ & Sangat Baik \\
\hline 5 & Navigasi & & & & 9 & 49 & $96,90 \%$ & Sangat Baik \\
\hline 6 & Daya dukung musik & & & & 8 & 50 & $97,24 \%$ & Sangat Baik \\
\hline 7 & Interaksi & & & & 2 & 56 & $99,31 \%$ & Sangat Baik \\
\hline \multicolumn{2}{|c|}{ Rata-rata } & & & $98,08 \%$ & Sangat Baik \\
\hline
\end{tabular}

Hasil penilaian uji coba lapangan terhadap aspek kualitas materi pembelajaran pada media pembelajaran interaktif berbasis komputer pada matakuliah menggambar teknik menyatakan bahwa untuk aspek kualitas materi pembelajaran pada uji coba lapangan menunjukkan 58 orang $(100,00 \%)$ menyatakan "Sangat Baik".

\section{Analisis Data Hasil Uji Coba Tahap II Uji Coba Perorangan}

Tabel 7. berikut menunjukkan persentase rata-rata hasil penilaian pada uji coba peorangan terhadap aspek kualitas materi pembelajaran sebesar $93,33 \%$ dan aspek kualitas atau teknis tampilan sebesar dan $89,52 \%$ dan masing-masing termasuk kategori sangat baik.

Tabel 7. Persentase Rata-Rata Hasil Penilaian Terhadap Media Pembelajaran Interaktif Berbasis Komputer Pada Matakuliah Menggambar Teknik Pada Uji Coba Perorangan

\begin{tabular}{|c|l|c|c|}
\hline No & \multicolumn{1}{|c|}{ Kategorisasi } & $\begin{array}{c}\text { Persentase rata- } \\
\text { rata }\end{array}$ & Kriteria \\
\hline 1 & Aspek kualitas materi pembelajaran & $93,33 \%$ & Sangat Baik \\
\hline 2 & Aspek kualitas teknis/tampilan & $89,52 \%$ & Sangat Baik \\
\hline \multicolumn{2}{|c|}{ Rata-rata } & $91,43 \%$ & Sangat Baik \\
\hline
\end{tabular}

Analisis Data Hasil Uji Coba Tahap III Uji Coba Kelompok Kecil.

Tabel 8. berikut menunjukkan persentase rata-rata dari hasil penilaian terhadap media pembelajaran interaktif berbasis komputer pada matakuliah menggambar teknik pada uji coba kelompok kecil terhadap aspek kualitas materi pembelajaran adalah sebesar 91,39\% dan aspek kualitas teknis atau tampilan sebesar $95,87 \%$ dan masing-masing termasuk kategori sangat baik.

Tabel 8. Persentase Rata-Rata Hasil Penilaian Terhadap Media Pembelajaran Interaktif Berbasis Komputer Pada Matakuliah Menggambar Teknik Pada Uji Coba Kelompok Kecil

\begin{tabular}{|l|l|c|c|}
\hline No & Kategorisasi & $\begin{array}{c}\text { Persentase rata- } \\
\text { rata }\end{array}$ & Kriteria \\
\hline 1 & Aspek kualitas materi pembelajaran & $91,39 \%$ & Sangat Baik \\
\hline 2 & Aspek kualitas teknis/tampilan & $95,87 \%$ & Sangat Baik \\
\hline \multicolumn{2}{|c|}{ Rata-rata } & $95,87 \%$ & Sangat Baik \\
\hline
\end{tabular}

\section{Analisis Data Hasil Uji Coba Tahap IV Uji Coba Lapangan}

Tabel 9. Persentase Rata-Rata Hasil Penilaian Terhadap Media Pembelajaran Interaktif Berbasis Komputer Pada Matakuliah Pelajaran Menggambar Teknik Pada Uji Coba Lapangan 


\begin{tabular}{|c|l|c|c|}
\hline No & \multicolumn{1}{|c|}{ Kategorisasi } & $\begin{array}{c}\text { Persentase rata- } \\
\text { rata }\end{array}$ & Kriteria \\
\hline 1 & Aspek kualitas materi pembelajaran & $97,84 \%$ & Sangat Baik \\
\hline 2 & Aspek kualitas teknis/tampilan & $98,08 \%$ & Sangat Baik \\
\hline \multicolumn{2}{|c|}{ Rata-rata } & $97,96 \%$ & Sangat Baik \\
\hline
\end{tabular}

Pengujian Hipotesis. Setelah dilakukan uji kelayakan data selesai maka selanjutnya dilakukan uji $\mathrm{t}$ pretes penelitian. Hal ini dilakukan untuk mengetahui apakah terdapat perbedaan kemampuan awal kelas kontrol dan kelas eksperiman dengan menggunakan uji $\mathrm{t}$ pretes. Berdasarkan hasil perhitungan pada diperoleh output $t_{\text {hitung }}$ sebesar $-1,385$ dan $t_{\text {tabel }}$ sebesar 1,67 pada taraf kepercayaan 95 persen. Maka diperoleh bahwa $t_{\text {hitung }}<\mathrm{t}_{\text {tabel }}$ atau $-1,385$ $<$ 1,67 atau dengan kata lain Ha ditolak. Hal ini menujukkan bahwa kemampuan awal mahasiswa baik kelas kontrol dan kelas eksperimen adalah cenderung sama dan tidak berbeda secara signifikan.

\section{Uji t postes}

Ho : $\mu_{1}=\mu_{2}$

Ha : $\mu_{1}>\mu_{2}$

Keterangan :

$\mu_{1}=$ Rata-rata hasil belajar mahasiswa yang diajar menggukan media pembelajaran interaktif.

$\mu_{2}=$ Rata-rata hasil belajar mahasiswa yang diajar dengan pembelajaran konvensional.

Ho = Tidak ada perbedaan hasil belajar menggambar teknik mahasiswa yang diajar dengan menggunakan media pembelajaran interaktif berbasis komputer lebih tinggi dari mahasiswa yang diajar dengan pembelajaran konvensional.

$\mathrm{Ha}=\mathrm{Ada}$ perbedaan hasil belajar menggambar teknik mahasiswa yang diajar dengan menggunakan media pembelajaran interaktif berbasis komputer lebih tinggi dari mahasiswa yang diajar dengan pembelajaran konvensional.

Setelah dilakukan uji t pretes selesai maka selanjutnya dilakukan pengujian hipotesis penelitian dengan menggunakan uji $\mathrm{t}$ postes. Hal ini dilakukan untuk mengetahui apakah ada perbedaan hasil belajar mahasiswa setelah dilakukan perlakuan yang berbeda.

Berdasarkan hasil perhitungan pada tabel diatas diperoleh output $t_{\text {hitung }}$ sebesar 3,285 dan $t_{\text {tabel }}$ sebesar 1,67 pada taraf kepercayaan 95 persen. Maka diperoleh bahwa $t_{\text {hitung }}>t_{\text {tabel }}$ atau 3,285 > 1,67 atau dengan kata lain Ho di tolak dan Ha diterima. Berdasarkan data-data di atas maka disimpulkan bahwa hasil belajar menggambar teknik mahasiswa yang diajar dengan menggunakan media pembelajaran interaktif berbasis komputer lebih tinggi dari mahasiswa yang diajar dengan pembelajaran konvensional teruji kebenarannya. Hal ini berarti hasil belajar mahasiswa yang menggunakan media pembelajaran interaktif berbasis komputer lebih tinggi dari hasil belajar mahasiswa yang diajar dengan pembelajaran konvensional dengan efektifitas penggunaan media interaktif sebesar $80,46 \%$. Nilai keefektifan media pembelajaran interaktif ini lebih tinggi dari nilai keefektifan pembelajaran tanpa media yaitu sebesar $71,72 \%$.

Berikut hasil rangkuman persentase rata-rata hasil penilaian terhadap media pembelajaran interaktif matakuliah menggambar teknik oleh ahli materi, ahli desain pembelajaran, ahli rekayasa perangkat lunak, uji coba perorangan, uji coba kelompok kecil dan uji coba lapangan dapat dilihat pada tabel 10 berikut ini.

Tabel 10. Rangkuman Persentase Rata-Rata Hasil Penilaian Terhadap Media Pembelajaran Interaktif Berbasi Komputer Pada Matakuliah Menggambar Teknik

\begin{tabular}{|l|l|c|l|}
\hline No & \multicolumn{1}{|c|}{ Responden } & Persentase Rata-rata & Kriteria \\
\hline 1 & Ahli materi & $93,83 \%$ & Sangat Baik \\
\hline 2 & Ahli desain pembelajaran & $88,55 \%$ & Sangat Baik \\
\hline 3 & Ahli rekayasa perangkat lunak & $94,10 \%$ & Sangat Baik \\
\hline 4 & Siswa pada uji coba perorangan & $91,43 \%$ & Sangat Baik \\
\hline 5 & Siswa pada uji coba kelompok kecil & $93,63 \%$ & Sangat Baik \\
\hline 6 & Siswa pada uji coba lapangan & $97,96 \%$ & Sangat Baik \\
\hline
\end{tabular}




\section{\begin{tabular}{|c|c|c|c|}
\hline & Rata-Rata & $\mathbf{9 3 , 2 5} \%$ & Sangat Baik \\
\hline
\end{tabular}}

\section{Pembahasan}

Produk pengembangan media pembelajaran interaktif pada matakuliah menggambar teknik merupakan materi pembelajaran yang telah dikembangkan dengan memperhatikan aspek pembelajaran dan media sebagai prinsip desain pesan pembelajaran. Penelitan pengembangan produk yang dilakukan ini diarahkan untuk menghasilkan suatu produk berupa media pembelajaran interaktif berbasis komputer pada matakuliah menggambar teknik untuk meningkatkan proses pembelajaran maupun kompetensi mahasiswa. Oleh sebab itu proses penelitian ini dilakukan dan diawali dengan, (1) studi pendahuluan, (2) kemudian mendesain media pembelajaran, (3) melakukan validasi produk dan melakukan revisi dan penyempurnaan berdasarkan analisis data validasi dari ahli materi, (4) ahli desain pembelajaran dan ahli rekayasa perangkat lunak yang dilanjutkan dengan uji coba perorangan, uji coba kelompok kecil, dan uji coba lapangan sehingga dihasilkan media pembelajaran yang layak digunakan sesuai dengan karakteristik bidang studi dan mahasiswa sebagai pengguna.

Aspek yang direvisi dan disempurnakan berdasarkan analisis data dan uji coba serta masukan dari ahli materi, ahli desain pembelajaran, ahli rekayasan perangkat lunak dan mahasiswa selaku pengguna media pembelajaran interaktif ini, bertujuan untuk menggali beberapa aspek yang lazim dalam proses pengembangan suatu produk. Variabelvariabel media pembelajaran memiliki nilai rata-rata sangat baik.Adapun variabel media pembelajaran yang dinilai meliputi kelayakan isi, penyajian, kebahasaan, pemrograman, dan kegrafikan.

Beberapa kegunaan dan manfaat dalam penggunaan media pembelajaran interaktif berbasis komputer pada matakuliah menggambar teknik sebagai berikut: (1) materi mudah dipahami karena konsep yang disajikan direncanakan untuk mempermudah mahasiswa dan sistematis, (2) media pembelajaran interaktif berbasis computer memberi kesempatan mahasiswa untuk belajar sesuai dengan kecepatan masing-masing individu, (3) belajar lebih cepat dan menarik sehingga tidak menimbulkan kebosanan karena dilengkapi dengan gambar-gambar dan animasi serta soal latihan yang bervariasi. (4) adanya kesempatan dalam menjawab soal pada waktu tes jika jawaban dianggap salah dengan tujuan agar mahasiswa dapat memahami materi yang telah dipelajari, (5) media pembelajaran interaktif ini juga dapat digunakan sebagai alternatif media pembelajaran secara konvensional maupun individual.

Dari hasil pengolahan data penelitian yang dilakukan, terdapat perbedaan hasil belajar matakuliah menggambar teknik antara mahasiswa yang dibelajarkan dengan menggunakan media pembelajaran interaktif dan mahasiswa yang dibelajarkan dengan tanpa menggunakan media pembelajaran interaktif yaitu rata-rata hasil belajar menggambar teknik mahasiswa yang dibelajarkan dengan menggunakan media pembelajaran interaktif lebih tinggi dibandingkan dengan mahasiswa yang dibelajarkan tanpa menggunakan media pembelajaran interaktif. Hal ini dapat dilihat dari hasil nilai rata-rata menggambar teknik mahasiswa yang yang diajar dengan media pembelajaran interaktif yaitu sebesar 12,06 $(80,46 \%)$, sedangkan hasil nilai rata-rata menggambar teknik mahasiswa yang diajar tanpa media pembelajaran interaktif sebesar 10,76 (71,72\%). Dari data ini membuktikan bahwa penggunaan media pembelajaran interaktif lebih baik dalam meningkatkan komptensi dan pengetahuan mahasiswa pada matakuliah menggambar teknik daripada tanpa menggunakan media pembelajaran interaktif.

Penggunaan media pembelajaran interaktif memungkinkan mahasiswa untuk lebih mudah memahami menggambar teknik karena dari media pembelajaran ini memungkinkan mahasiswa untuk berinteraksi langsung, memiliki gambar-gambar, animasi, sound background dan soal yang hasilnya dapat dikirim langsung melalui e-mail dosen, sehingga setiap mahasiswa tidak kesulitan lagi dalam membayangkan dalam hal membaca gambar karena didalam media ini telah dijelaskan secara detail. Selain itu, media pembalajaran ini sangat praktis, karena media ini dapat dibawa oleh mahasiswa dan dapat dipelajari dirumah karena media pembelajaran interaktif tersebut dalam bentuk flash. Media pembelajaran ini juga dapat menguji kemampuan dan pemahaman mahasiswa secara langsung melalui tes atau soal-soal latihan pilihan berganda yang memiliki durasi waktu dan kunci jawaban yang benar, sehingga mahasiswa dapat mengetahui kesalahan yang telah dilakukan dalam mengerjakan soal latihan tersebut. Media pembelajaran interaktif juga 
dilengkapi dengan rangkuman yang dapat membantu mahasiswa memperoleh ringkasan materi kuliah yang dipaparkan.

Pembelajaran dengan media pembelajara interaktif berbasis kmputer juga memungkinkan para dosen pengampuh bebas melakukan interaksi dengan mahasiswa sehingga pembelajaran tersebut bersifat interaktif yang membuat pembelajaran terfokus pada informasi yang sedang dipelajari. Hal ini berbeda dengan pembelajaran tanpa menggunakan media pembelajaran interaktif, mahasiswa tidak berinteraksi langsung pada sumber informasi dan pembelajaran didominasi oleh dosen yang menyajikan informasi secara linier atau satu arah, selain itu dalam pembelajaran matakuliah menggambar teknik sangat dituntut mahasiswa untuk mampu membaca gambar, membuat gambar dan membayangkan gambar proyeksi. Hal tersebut tentunya akan cukup menyulitkan dan membuat perkuliahan menjadi kurang menarik. Tanpa media pembelajaran interaktif berbasis komputer mahasiswa mendapatkan sumber informasi hanya dari dosen yang bersangkutan dengan materi-materi yang ada pada buku. Pembelajaran tanpa menggunakan media interaktif menempatkan dosen menggunakan kontrol pembelajaran dengan aktif, sementara mahasiswa relatif pasif menerima dan mengikuti apa yang disampaikan dosen. Dosen menyampaikan materi secara terstruktur dengan harapan materi kuliah yang disampaikan dapat dikuasai dengan baik dengan terfokus kepada kemampuan akademik.

Walaupun dalam penelitian diperoleh data bahwa hasil belajar matakuliah menggambar teknik mahasiswa lebih tinggi jika dibelajarkan dengan menggunakan media pembelajaran interaktif dari pada hasil belajar menggambar teknik mahasiswa yang dibelajarkan tanpa menggunakan media pembelajaran interaktif, namun dalam pelaksanaannya kedua media pembelajaran ini telah mampu meningkatkan pemahaman dan hasil belajar menggambar teknik mahasiswa. Keefektifan penggunaan media pembelajaran interaktif adalah sebesar 80,46\% dan tanpa media sebesar $71,72 \%$.

\section{PENUTUP}

\section{Simpulan}

Berdasarkan rumusan, tujuan, hasil dan pembahasan penelitian pengembangan media pembelajaran interaktif berbasis komputer yang dikemukakan sebelumnya maka dapat disimpulkan sebagai berikut:

1. Hasil validasi dari ahli materi terhadap media pembelajaran interaktif berbasis komputer pada matakuliah menggambar yang dikembangkan menunjukkan bahwa; (1) kualitas materi pembelajaran dinilai sangat baik, (2) kualitas strategi pembelajaran dinilai sangat baik, (3) kualitas sistem penyampaian pembelajaran dinilai sangat baik. Hasil validasi dari ahli desain pembelajaran terhadap media pembelajaran interaktif berbasis komputer pada matakuliah menggambar teknik yang dikembangkan dengan menggunakan beberapa program dan Macromedia Flash Professional 8.0 menunjukkan bahwa; (1) kualitas desain pembelajaran dinilai sangat baik, (2) kualitas desain informasi dinilai sangat baik, (3) kualitas desain interaksi dinilai baik, (4) kualitas desain presentasi dinilai sangat baik. Hasil validasi dari ahli rekayasa perangkat lunak terhadap media pembelajaran interaktif berbasis komputer pada matakuliah menggambar teknik yang dikembangkan dengan beberapa program dan Macromedia Flash Professioanal 8.0 dinyatakan bahwa; (1) pemrograman dinilai sangat baik, (2) kualitas teknis/tampilan dinilai sangat baik.

2. Menurut tanggapan mahasiswa Fakultas Teknik Jurusan Pendidikan Teknik Mesin Universitas Negeri Medan pada uji coba perorangan dinyatakan bahwa media pembelajaran interaktif yang dikembangkan dengan beberapa program dan Macromedia Flash Professional 8.0 termasuk kategori sangat baik. Menurut tanggapan mahasiswa Fakultas Teknik Jurusan Pendidikan Teknik Mesin Universitas Negeri Medan pada uji coba kelompok kecil dinyatakan bahwa media pembelajaran interaktif yang dikembangkan dengan beberapa program dan Macromedia Flash Professional 8.0 termasuk kategori sangat. Menurut tanggapan mahasiswa Fakultas Teknik Jurusan Pendidikan Teknik Mesin Universitas Negeri Medan pada uji coba lapangan dinyatakan bahwa media pembelajaran interaktif yang dikembangkan dengan beberapa program dan Macromedia Flash Professional 8.0 termasuk kategori sangat baik.

3. Terhadap penggunaan media pembelajaran interaktif pada tes hasil belajar mahasiswa 
menunjukkan bahwa hasil belajar mahasiswa yang dibelajarkan dengan menggunakan media pembelajaran interaktif berbasis komputer (kelas eksperimen) lebih tinggi $=12,06$ dari hasil belajar mahasiswa yang dibelajarkan dengan menggunakan media pembelajaran buku teks (kelas kontrol) $=10,76$. Dengan demikian disimpulkan bahwa terdapat perbedaan yang signifikan antara hasil belajar mahasiswa yang dibelajarkan dengan menggunakan media pembelajaran inetraktif dengan hasil belajar mahasiswa yang dibelajarkan dengan media pembelajaran buku teks.

\section{Saran}

Berdasarkan hasil temuan yang telah diuraikan pada kesimpulan serta implikasi hasil penelitian, berikut ini diajukan beberapa saran yaitu:

1. Media pembelajaran interaktif ini adalah alat untuk membantu dalam proses penyampaian pembelajaran khususnya matakuliah menggambar teknik maka dari itu keberadaan dosen masih sangat diperlukan sebagai fasilitator dan mahasiswa tetap terlibat aktif dalam proses pembelajaran matakuliah menggambar teknik.

2. Pada kenyataannya hingga saat ini proses pembelajaran matakuliah menggambar teknik masih dilakukan dengan cara konvensional dengan menggunakan media pembelajaran buku teks, maka disarankan agar media pembelajaran interaktif berbasis komputer mulai saat ini sudah harus digunakan dengan alasan media pembelajaran interaktif mampu memberi umpan balik yang lebih baik bagi mahasiswa.

3. Pada prodi teknologi pendidikan hendaknya diadakan sarana dan prasarana yang mendukung matakuliah produksi media yang bersifat pada produk dan adanya pembelajaran flash maupun software yang dapat digunakan untuk produksi media yang lainnya pada prodi teknologi pendidikan yang bertujuan untuk bekal dan mempermudah mahasiswa dalam proses pembuatan media pembelajaran interaktif (khususnya dalam penelitian R\&D berbasis TIK).

\section{DAFTAR PUSTAKA}

AECT. (1977). Definisi teknologi pendidikan (satuan tugas definisi \& terminologi AECT). Jakarta. Rajawali.

Budiningsih, Asri . (2003). Desain pesan pembelajaran. Yogyakarta : Fakultas Ilmu Pendidikan Universitas Negeri Yogyakarta.

Borg, W. \&V Gall, M.D. (1983). Educational research. An introduction ( $\left.4^{\text {nd }} \mathrm{ed}\right)$. New York \& London: Longman.

Brandie Colon, Key Ann Taylor dan Jerry Willis. (2000). Constructivist instructional design: Creating multimedia package for teaching critical qualitative research. The qualitative report, volume 5, number $1 \& 2$, May 2000. Diambil tanggal 20 Juli 2006 dari http://www.nova-edu/SSSS/QR/QR51/colon.html.

Degeng, I Nyoman Sudana. (1989). Ilmu pengajaran taksonomi variabel. Jakarta : PPLPTK, DEPDIKBUD

Dick, W. dan Cary, L. (2005). The systematic design of instruction. United States of America: Scott Foresman and Company.

Djamarah dan Zein. (2006). Strategi Belajar Mengajar. Jakarta: Rineka Cipta.

Gagne, Robert M and Briggs, Leslie J. (1979). Principles of Instructional Design $\left(2^{\text {nd }}\right.$ $E d$.). New York: Holt, Rinehart and Winston.

Hacbart, Steven. (1996). The educational technology hand book. New Jersey. Educational Technology Publications, Inc.

Heinich, Robert, et. Al. (1996) Instructional media and technologies for learning $\left(5^{\text {th }}\right.$ ed). New Jersey : A Simon \& Schuster Company Engelewood Cliffs.

Hornby. A.S. 1985. Oxford Advanced Learner's Dictionary of Current English, Oxford USA: Oxford University Pres.

Hakim, Lukmanul. (2003). Teknik jitu menguasai macromedia flash MX 2004. Jakarta: Elex Media Komputindo.

(2004). Cara ampuh menguasai macromedia flash MX 2004. Jakarta: Elex Media Komputindo.

Kemp. (1994). Design effective instruction. New York: Macmillan College Publishing Company.

Lambert, (1992). Why interactive multimedia based computer aided learning (IMMCAL). Diambil tanggal 5 Januari 2006, dari 
http://www.ascilite.org.au/asetarchives/c onfs/iims/1992/lambert-t.html

Mukminan. (2004). Desain pembelajaran. Yogyakarta: Program Pascasarjana Universitas Negeri Yogyakarta.

Mansur, Muslich. 2008. KTSP. Pembelajaran Berbasis Kompetensi dan Kontekstual. Jakarta : Bumi Aksara.

Nolker,. Helmut and Schoenfeldt, Eberhard. 1988. berufsbildung: Unterricht, Curriculum, Platung (Pendidikan Kejuruan: Pengajaran, Kurikulum, Perencanaan). Penerjemah: Agus Setiadi. Jakarta: P.T. Gramedia. Porter Boby et all, (2001). Quantum teaching. Jakarta : Kaifa

Rob Phillips, (1997). Interactive multimedia. Boston: Kogan Page

Romiszowski. (1988). The selection and use of instructional media. United States: Nichols Publishing.

Sato, G.T. dan Hartanto, N.S. 2004. Menggambar Mesin Menurut standar ISO. Jakarta: PT Pradnya paramita.

Seells dan Richey. 1996). Instructional technology (Mahasiswa S2 IKIP Malang Terjemahan). IKIP Malang
Slameto, 2003, Belajar dan faktor-faktor yang mempengaruhinya, Jakarta : Rhineka Cipta.

Sleeman, Philip. J. (1979). Instructional media and technology. New York: Long man Inc.

Suparman M, Atwi. (2001). Desain instruksional. Pusat antar Universitas untuk Peningkatan dan Pengembangan Aktivitas Instruksional. Jakarta: Direktorat Jenderal Pendidkan Tinggi, Departemen Pendidikan Tinggi. (2001).

Sukardjo. (2000). Kecenderungan baru (trend) teknologi pembelajaran kimia. Makalah disajikan pada Seminar Regional di Jurdik Kimia UNY.

Waddington , D.J. (1984). Teaching school chemistry . Paris : Unesco.

Waldopo. (2002). Penelitian dan pengembangan, pendekatan dalam mengembangkan produk-produk di bidang pendidikan pembelajaran. Jurnal Teknodik. Desember 2002. Jakarta: Pustekkom. 